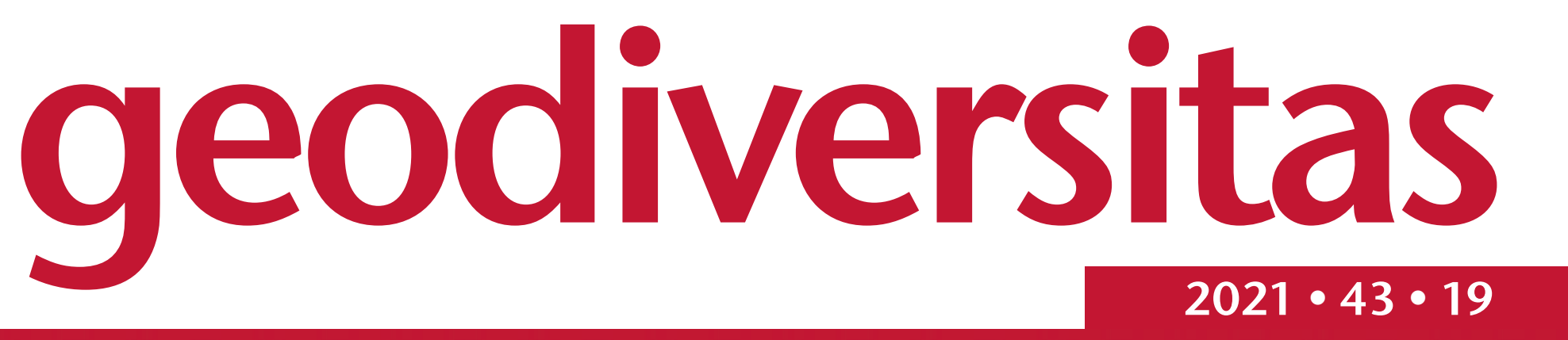

Naja romani (Hoffstetter, 1939) (Serpentes: Elapidae) from the late Miocene of the Northern Caucasus: the last East European large cobra

Elena SYROMYATNIKOVA, Alexey TESAKOV \& Vadim TITOV
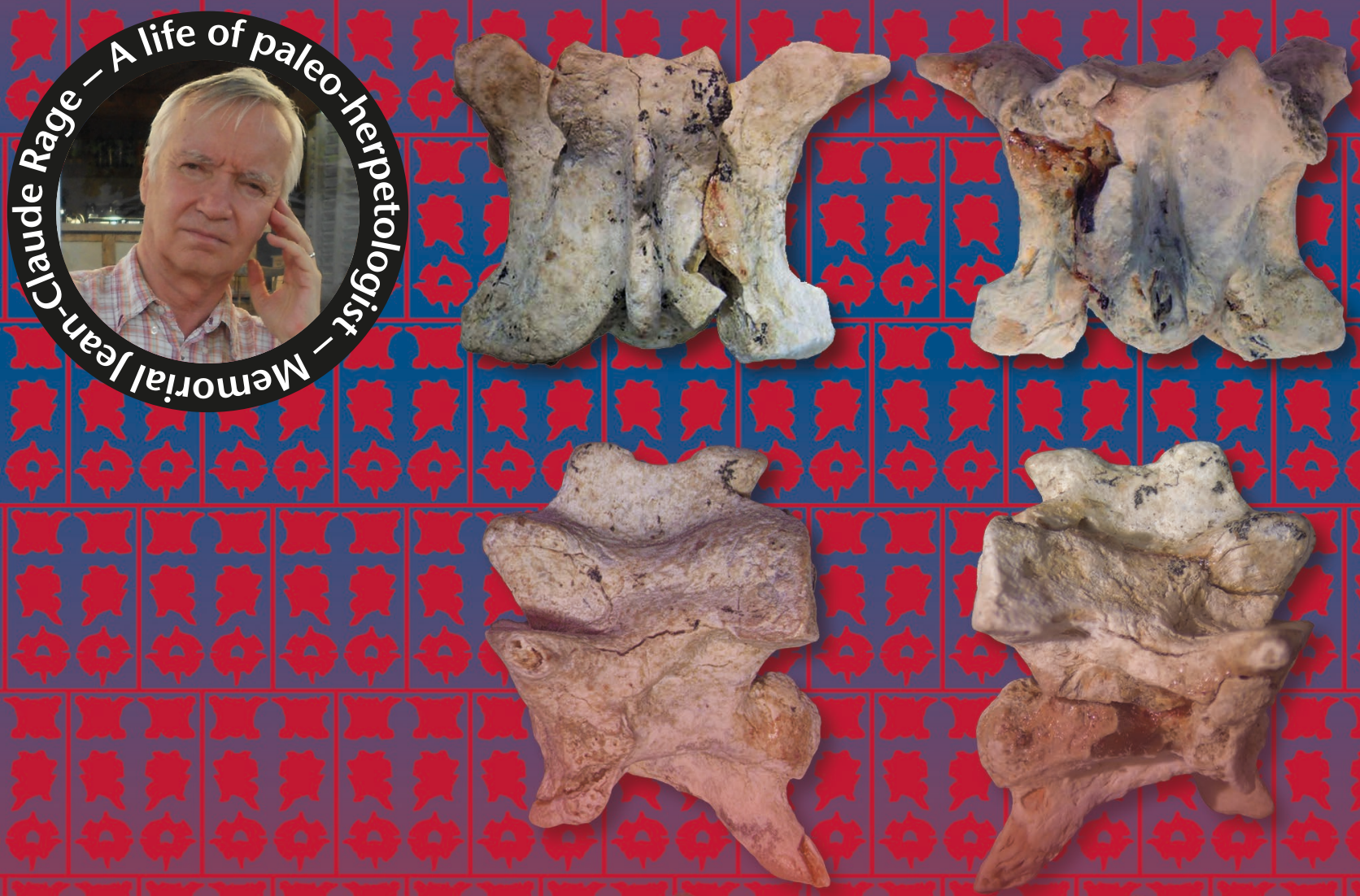
DiReCteur de LA PUblication / PUBLICATION DIRECTOR : Bruno David,

Président du Muséum national d'Histoire naturelle

RÉDACTEUR EN CHEF / EDITOR-IN-CHIEF: Didier Merle

ASSISTANT DE RÉDACTION / ASSISTANT EDITOR: Emmanuel Côtez (geodiv@mnhn.fr)

Mise EN PAGE / PAGE LAYOUT: Emmanuel Côtez

COMITÉ SCIENTIFIQUE / SCIENTIFIC BOARD:

Christine Argot (Muséum national d'Histoire naturelle, Paris)

Beatrix Azanza (Museo Nacional de Ciencias Naturales, Madrid)

Raymond L. Bernor (Howard University, Washington DC)

Alain Blieck (chercheur CNRS retraité, Haubourdin)

Henning Blom (Uppsala University)

Jean Broutin (Sorbonne Université, Paris, retraité)

Gaël Clément (Muséum national d'Histoire naturelle, Paris)

Ted Daeschler (Academy of Natural Sciences, Philadelphie)

Bruno David (Muséum national d'Histoire naturelle, Paris)

Gregory D. Edgecombe (The Natural History Museum, Londres)

Ursula Göhlich (Natural History Museum Vienna)

Jin Meng (American Museum of Natural History, New York)

Brigitte Meyer-Berthaud (CIRAD, Montpellier)

Zhu Min (Chinese Academy of Sciences, Pékin)

Isabelle Rouget (Muséum national d'Histoire naturelle, Paris)

Sevket Sen (Muséum national d'Histoire naturelle, Paris, retraité)

Stanislav Štamberg (Museum of Eastern Bohemia, Hradec Králové)

Paul Taylor (The Natural History Museum, Londres, retraité)

COUVERTURE / COVER:

Réalisée à partir des Figures de l'article/Made from the Figures of the article.

Geodiversitas est indexé dans / Geodiversitas is indexed in:

- Science Citation Index Expanded (SciSearch ${ }^{\circledR}$ )

- ISI Alerting Services ${ }^{\circledR}$

- Current Contents ${ }^{\circledR}$ / Physical, Chemical, and Earth Sciences ${ }^{\circledR}$

- Scopus ${ }^{\circledR}$

Geodiversitas est distribué en version électronique par / Geodiversitas is distributed electronically by:

- BioOne ${ }^{\circledR}$ (http://www.bioone.org)

Les articles ainsi que les nouveautés nomenclaturales publiés dans Geodiversitas sont référencés par / Articles and nomenclatural novelties published in Geodiversitas are referenced by:

- ZooBank ${ }^{\circledR}$ (http://zoobank.org)

Geodiversitas est une revue en flux continu publiée par les Publications scientifiques du Muséum, Paris Geodiversitas is a fast track journal published by the Museum Science Press, Paris

Les Publications scientifiques du Muséum publient aussi / The Museum Science Press also publish: Adansonia, Zoosystema, Anthropozoologica, European Journal of Taxonomy, Naturae, Cryptogamie sous-sections Algologie, Bryologie, Mycologie, Comptes Rendus Palevol

Diffusion - Publications scientifiques Muséum national d'Histoire naturelle

CP $41-57$ rue Cuvier F-75231 Paris cedex 05 (France)

Tél. : 33 (0)1 40794805 / Fax: 33 (0)14079 3840

diff.pub@mnhn.fr / http://sciencepress.mnhn.fr

(C) Publications scientifiques du Muséum national d'Histoire naturelle, Paris, 2021

ISSN (imprimé / print): 1280-9659/ ISSN (électronique / electronic): 1638-9395 


\title{
Naja romani (Hoffstetter, 1939) (Serpentes: Elapidae) from the late Miocene of the Northern Caucasus: the last East European large cobra
}

\author{
Elena SYROMYATNIKOVA \\ A.A. Borissiak Paleontological Institute, Russian Academy of Sciences, \\ Profsoyuznaya str., 123, Moscow, 117647 (Russia) \\ and Zoological Institute, Russian Academy of Sciences, \\ Universitetskaya emb., 1, St. Petersburg, 199034 (Russia) \\ esyromyatnikova@gmail.com \\ sev@paleo.ru \\ (corresponding author) \\ Alexey TESAKOV \\ Geological Institute of the Russian Academy of Sciences, \\ Pyzhevsky per., 7, Moscow, 119017 (Russia) \\ tesak@ginras.ru \\ tesak-ov@yandex.ru \\ Vadim TITOV \\ Southern Scientific Centre, Russian Academy of Sciences, \\ Chekhov str. 41, 344006 Rostov-on-Don (Russia) \\ vvtitov@yandex.ru
}

Submitted on 26 September 2019 | accepted on 23 March 2020 | published on 23 September 2021

urn:Isid:zoobank.org:pub:1EE3B267-DFAE-4F6B-A362-90E4AE36E31A

Syromyatnikova E., Tesakov A. \& Titov V. 2021. - Naja romani (Hoffstetter, 1939) (Serpentes: Elapidae) from the late Miocene of the Northern Caucasus: the last East European large cobra, in Steyer J.-S., Augé M. L. \& Métais G. (eds), Memorial JeanClaude Rage: A life of paleo-herpetologist. Geodiversitas 43 (19): 683-689. https://doi.org/10.5252/geodiversitas2021v43a19. http://geodiversitas.com/43/19

\section{ABSTRACT}

A new record of the genus Naja Laurenti, 1768 is described from the latest Miocene of Solnechnodolsk locality in Russia. It is assigned to N. romani (Hoffstetter, 1939), the largest European cobra, which disappeared in Europe before the end of the Miocene. The record of $N$. romani is the first evidence of the survival of cobras to the latest Miocene of Eastern Europe, which points to the ex-

KEY WORDS

Elapidae,

cobra,

Miocene,

Neogene,

Eastern Europe,

new record. istence of a Caucasian refugium during the late Miocene. The large size of the vertebra of the cobra from Solnechnodolsk indicates that it belonged to one of the largest specimens of this taxon. Naja romani from Solnechnodolsk represents the first record of cobras in Russia and the Northern Black Sea area, contributing to the knowledge of ancient biodiversity of the region and suggesting a wider range for the genus. Naja romani was a thermophilous snake that indicates a subtropical character of the Solnechnodolsk fauna. 


MOTS CLÉS
Elapidae,
cobra,
Miocène,
Néogène,
Europe de PEst,
signalement nouveau.

MOTS CLÉS

cobra,

Miocène,

signalement nouveau.

\begin{abstract}
RÉSUMÉ
Naja romani (Hoffstetter, 1939) (Serpentes: Elapidae) du Miocène supérieur du Caucase du Nord: le dernier grand cobra d'Europe de l'Est.

Une nouvelle occurrence du genre Naja Laurenti, 1768 est signalée dans le Miocène supérieur de la localité de Solnechnodolsk en Russie. L'espèce est attribuée à N. romani (Hoffstetter, 1939), le plus grand cobra européen, qui aurait disparu en Europe avant la fin du Miocène. L'enregistrement de $N$. romani est la première preuve de la survie des cobras dans le Miocène supérieur d'Europe de l'Est, ce qui indique l'existence d'un refuge caucasien pendant le Miocène supérieur. La grande taille de la vertèbre du cobra de Solnechnodolsk indique qu'elle appartenait à l'un des plus grands spécimens de ce taxon. Naja romani de Solnechnodolsk représente ainsi la première occurrence de cobras en Russie et dans la région nord de la Mer Noire. Ce résultat contribue à la connaissance de la paléobiodiversité de la région et suggère une extension de l'aire de répartition de ce serpent. Naja romani était un serpent thermophile, ce qui indique le caractère subtropical de la faune de Solnechnodolsk.
\end{abstract}

\section{INTRODUCTION}

Cobras (family Elapidae) do not currently inhabit the European continent, but are densely documented in the Neogene European fossil record (Szyndlar 1985; Szyndlar \& Rage 1990; Szyndlar \& Zerova 1990; Szyndlar 1991). According to traditional morphology-based hypothesis, the European fossil cobras belong to the living genus Naja Laurenti, 1768, which can be divided into two lineages: a) extant African species and the Miocene N. antiqua Rage, 1976 from Africa and N. iberica Szyndlar, 1985 from Spain; and b) extant Asiatic species and the Miocene $N$. romani (Hoffstetter, 1939) from Austria, Germany, Greece, Hungary, France, and Ukraine (Szyndlar \& Rage 1990). However recent molecular studies announced a different scenario (Quadros et al. 2019). The first probable elapid snakes that appeared in Europe were the largesized cobra Naja romani. This species was originally described from the middle Miocene (MN 7+8) of La Grive-Saint-Alban in France (Hoffstetter 1939) and later was widely reported from ophidian assemblages extending from the early (MN 4) to the late (MN 11) Miocene (Bachmayer \& Szyndlar 1985; Szyndlar \& Rage 1990; Szyndlar \& Schleich 1993). Apart from the type locality, remains of Naja romani come from the early Miocene (MN 4) of Petersbuch 2 in Germany (Szyndlar \& Schleich 1993), middle Miocene (MN 5) of Grund in Austria (Tempfer 2003), late Miocene (MN 9) of Gritsev in Ukraine (Szyndlar \& Zerova 1990), late Miocene (MN 9) of Rudabánya in Hungary (Szyndlar 2005), and the late Miocene (MN 11) of Kohfidisch in Austria (as N. austriaca; Bachmayer \& Szyndlar 1985, 1987; as N. romani; Szyndlar \& Zerova 1990; Tempfer 2005). The latter record of Naja from Kohfidisch were described as a new extinct species, $N$. austriaca Bachmayer \& Szyndlar, 1985 (Bachmayer \& Szyndlar 1985). Later, based on detailed examination of the collection from Kohfidisch and its comparison with the type material of $N$. romani from La Grive-Saint-Alban, Szyndlar \& Zerova (1990) synonymized $N$. austriaca with $N$. romani. Remains of cobras assigned to Naja cf. romani are known from the early/middle Miocene (MN 4/5) of Vieux-Collonges in France (Ivanov 2000) and from the late Miocene (MN 10) of Greece (Ravin de la Pluie; Georgalis et al. 2018). During the late Pliocene cobras were still present in Europe and western Asia, but their distribution was restricted to the west (Spain and France) and east (Greece and Turkey) of the Mediterranean region, where they are documented only by few isolated vertebrae of Naja sp. (Rage \& Sen 1976; Jaen \& Sanchiz 1985; Bailon 1989, 1991; Szyndlar \& Zerova 1990; Szyndlar \& Rage 1990, Szyndlar 1995; Bailon \& Blain 2007; Georgalis et al. 2018, 2019). In Europe Naja romani disappeared entirely before the end of the Miocene. Accordingly, the geologically youngest record of $N$. romani comes from the MN 11 of Kohfidisch (Bachmayer \& Szyndlar 1985, 1987) and this species is not known after the middle late Miocene.

Below we describe a specimen of cobra from the latest Miocene (late Turolian, MN 13) of the Northern Caucasus (locality of Solnechnodolsk). This record represents the latest record of Naja romani and enlarges the geographic and geological range of this species.

\section{MATERIAL AND METHODS}

The vertebra of Naja romani described below comes from Solnechnodolsk locality $\left(45^{\circ} 18^{\prime} \mathrm{N}, 41^{\circ} 33^{\prime} \mathrm{E}\right.$; Fig. 1$)$ situated in the Northern Caucasus, $40 \mathrm{~km} \mathrm{NW}$ of the city of Stavropol. The locality yielded one of the most abundant and diverse vertebrate faunas of the late Miocene in Russia. The vertebrate fossils occurred as disassociated bones coming from 9 $\mathrm{m}$ thick section of a fluviatile and lacustrine silty and sandy beds incised in the Middle Sarmatian (Bessarabian) marine sands and limestones. Bone accumulations occur at the top of the section in lenses of silty sands, locally enriched in gravel size carbonate concretions. The fossil herpetofauna have been partly described (Syromyatnikova et al. 2015; Čerňanský et al. 2018; Syromyatnikova 2019; Čerňanský \& Syromyatnikova $2019 \mathrm{a}, \mathrm{b})$ and preliminary accounts of the vertebrate fauna were given by Tesakov et al. $(2010,2013)$ and Titov \& Tesakov (2013). The small mammals association with dominant Psudocricetus cf. kormosi and Apodemus cf. gorafensis indicates the correlation of the Solnechnodolsk fauna with late Turolian and the MN13 unit of the European Neogene Mammal biochronological system. The composition of the typical Hipparion association of large and small verterbrates testifies to the presence of a savanna-like landscape with different steppe, 


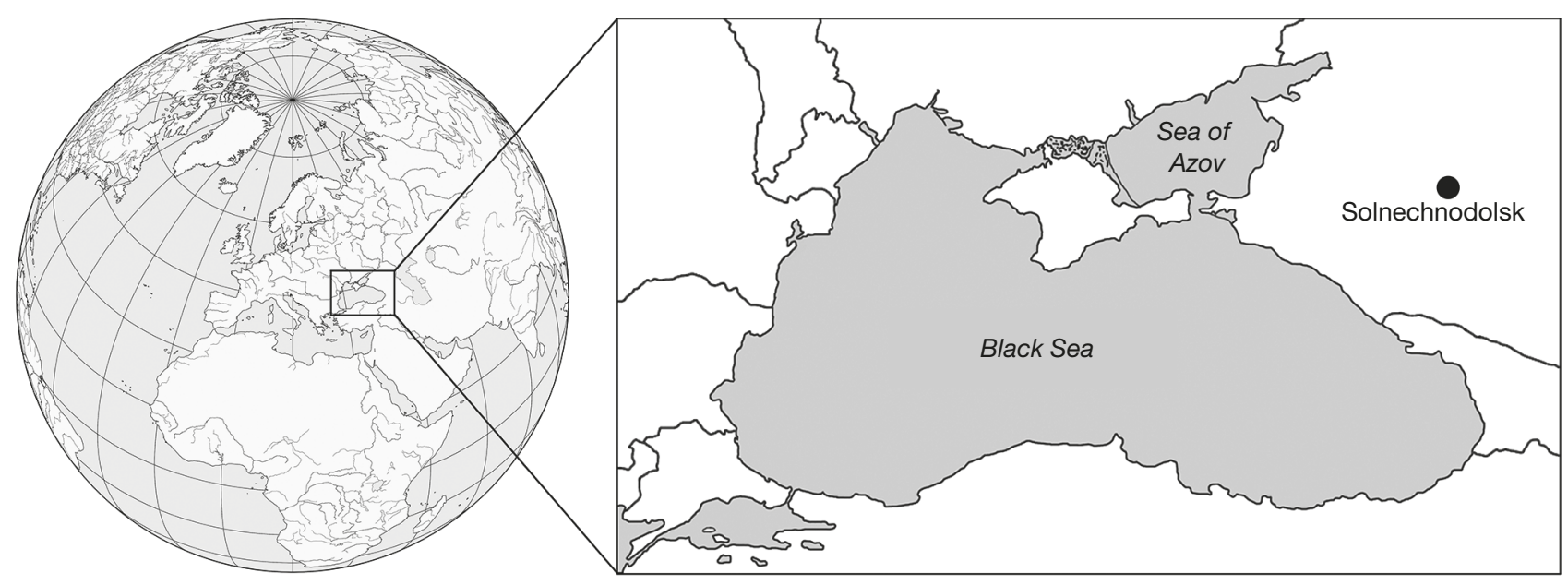

FIG. 1. - Location of the Solnechnodolsk locality.

wooded, and riparian biotopes. The vertebra of Naja romani here described was collected in 2009 by the expedition of the Russian Academy of Sciences. The specimen was found during the screen-washing of fossiliferous deposits. The degree of fossilization is the same as in other numerous bone finds from the locality. The specimen was photographed using the ZEISS Stemi 508 microscope in the Paleontological Institute of the Russian Academy of Sciences in Moscow (Russia). The general osteological terminology follows Szyndlar (1985). The terminology for portions of the snake vertebral column follows Polly et al. (2001) who distinguished precloacal (body) and postcloacal (tail) vertebrae. We herein follow the traditional view that the Neogene cobras from Europe are assigned to the single genus Naja. The described fossil material of Naja romani is deposited in the Geological Institute of the Russian Academy of Sciences, Moscow (GIN hereafter).

\section{SYSTEMATIC PALAEONTOLOGY}

Order SQUAMATA Oppel, 1811

Suborder SERPENTES Linnaeus, 1758

Family ElaPIDAE Boie, 1827

Genus Naja Laurenti, 1768

Naja romani (Hoffstetter, 1939) (Fig. 2)

MATERIAL EXAMINED. - One precloacal vertebra GIN 1145/305, Solnechnodolsk locality, Northern Caucasus, Russia; late Turolian, MN 13.

\section{DESCRIPTION}

The vertebra is large and robust with a centrum length of $9.2 \mathrm{~mm}$ and width of $9.7 \mathrm{~mm}$. The CL/NAW (centrum length/ width of interzygapophyseal constriction) ratio is 0.95 . The constriction between the pre- and postzygapophyses is weakly developed. From the ventral view, the subcentral ridges are well developed and relatively straight. The subcentral grooves are deep. The hypapophysis is very long and laterally compressed. It is directed ventrally and slightly posteriorly, with its posterior tip being obtuse and protruding posteriorly to the level of the condyle. The neural spine is relatively long and low, and incomplete in its mid length. The neural arch is markedly vaulted. The synapophyses are broken, but the left parapophyseal process is partly preserved and projected anteriorly and slightly ventrally. The zygosphenal roof is concave in dorsal view, presenting a small prominence in the middle of its width that can be considered as minute median lobe. In anterior view, the zygosphenal roof is straight. The prezygapophyseal articular facets are nearly circular. The prezygapophyseal process is missing on the left side, but completely present on the right side where it is well developed and relatively long (about half as long as the prezygapophyseal articular facet). It is obtuse distally. The postzygapophyseal articular facets are nearly rounded. The cotyle is slightly dorsoventrally compressed whereas the condyle is circular. The subcentral, lateral, and paracotylar foramina are clearly visible. The lateral and paracotylar foramina are situated in deep and wide depressions.

\section{COMPARISON AND REMARKS}

The presence of hypapophysis is a typical distinctive feature for snakes of the families Natricidae, Viperidae, and Elapidae (Szyndlar 1991). Thus, the vertebra GIN $1145 / 305$ can be assigned to one of these groups. The large size, robustness, and inclination of hypapophysis (directed ventrally rather than postero-ventrally) preclude the attribution of GIN 1145/305 to Natricidae. The shape and inclination of hypapophysis in GIN 1145/305 correspond to that of the vertebrae of Viperidae, however the vertebrae of the latter group have a dorso-ventrally depressed neural arch and larger cotyle and condyle. The laterally compressed hypapophysis and the very low neural spine observed in GIN 1145/305 are characteristic of Elapidae and "Naja group" (Szyndlar 1991). Elapid fossil finds often offer, well preserved cranial elements, which are useful keys for determining the fossil species. Accordingly, isolated elapid vertebrae are not very informative. Naja romani is currently the only recognized species of Naja in Central and 
Eastern Europe (a possible alternative opinion was announced by Quadros et al. 2019). The material herein can be assigned to $N$. romani based on long prezygapophyseal processes and presence of the concave zygosphene with minute median lobe. The vertebra likely comes from the anterior precloacal region of the vertebral column based upon the relatively vaulted neural arch and the morphology of the hypapophysis, which is directed rather ventrally than postero-ventrally.

The precloacal vertebrae of $N$. romani are well described from Kohfidisch, Petersbuch 2 and Vieux-Collonges. In contrast to the precloacal vertebrae of $N$. romani from Kohfidisch (originally described as $N$. austriaca Bachmayer \& Szyndlar, 1985 and synonymized with $N$. romani by Szyndlar \& Zerova in 1990 ), in the vertebra from Solnechnodolsk the neural arch is vaulted and the hypapophysis is narrower and more ventrally directed. The vertebra from Solnechnodolsk is more similar to the vertebra of $N$. romani described as cervical (Szyndlar 1985: fig. 5.9) in direction of the hypapophysis, but the latter one is widely rounded distally in lateral view.

The material attributed to $N$. romani from Petersbuch 2 presents several precloacal vertebrae (Szyndlar \& Schleich 1993). Among them, the vertebra from Solnechnodolsk is most similar to those described as anterior cervical vertebrae (Szyndlar \& Schleich 1993: fig. 7C-D) in presenting a slender hypapophysis. However, the vertebra from Solnechnodolsk differs from the anterior cervical from Petersbuch 2 in retaining a more anteriorly directed parapophyseal process. The vertebra from Solnechnodolsk is also similar to the anterior precloacal vertebra of Naja cf. romani from Vieux-Collonges (Ivanov 2000: fig. 12A-D). However, the vertebra from Solnechnodolsk clearly differs from all known precloacal vertebrae of Naja romani in having less developed interzygapophyseal constriction. The only exception is the vertebra with poorly developed interzygapophyseal constriction from Kohfidisch figured by Tempfer (2005: pl. 10a-d). In having the poorly developed interzygapophyseal constriction the vertebra from Solnechnodolsk is more reminiscent of Naja from the late Pliocene of Tourkobounia 1 (Greece; Szyndlar \& Zerova 1990). Among the other species of Naja, precloacal vertebrae were described for $N$. iberica (Szyndlar 1985). The vertebra from Solnechnodolsk differs from anterior precloacal vertebrae of $N$. iberica in having a distally pointed hypapophysis and from posterior precloacal vertebrae in having a more obtuse prezygapophyseal processes.

It is worth noting that intracolumnar variation of some precloacal vertebrae of Naja romani was mentioned by Szyndlar \& Zerova (1990) and Szyndlar (2005). There is no doubt that intracolumnar variation is also present in the anterior precloacal region, though it is not described due to the scarcity of the material. Until new material from different vertebral regions are discovered for $N$. romani, we consider the abovementioned variations of Naja from Solnechnodolsk (poorly developed interzygapophyseal constriction and morphology of the hypapophysis) to be intracolumnar variations.

\section{DISCUSSION}

The elapid record described above is represented by a single vertebra, but its systematic assignment to Naja romani is supported by characteristic morphology with long prezygapophyseal processes and presence of the concave zygosphene with minute median lobe. The vertebra comes from anterior precloacal region of the vertebral column. However, it differs from other known anterior precloacal vertebrae of Naja romani in its poorly developed interzygapophyseal constriction and the morphology of the hypapophysis (see section Comparison and Remarks above) possibly reflecting intracolumnar variations.

The centrum length of Solnechnodolsk vertebra is $9.2 \mathrm{~mm}$ with a CL/NAW ratio of 0.95 , that is only slightly smaller than the size of the largest precloacal vertebrae from Kohfidisch which has a centrum length ranging between 9.53 and 10.80 $\mathrm{mm}$ and a centrum length/width ratio of 0.82-0.99 (Bachmayer \& Szyndlar 1985). The smaller sizes were indicated for precloacal vertebrae from Petersbuch 2 , with centrum lengths ranging between 6.4 and $9.3 \mathrm{~mm}$ and centrum length/width ratios of 1.0-1.4. The vertebrae from Petersbuch 2 are close in length and proportions to vertebrae from Vieux-Collonges, with centrum lengths ranging between 6.21 and $8.75 \mathrm{~mm}$ and centrum length/width ratios of 1.01-1.28. Given that the vertebra from Solnechnodolsk comes from anterior precloacal region, the more posterior precloacal vertebrae of this animal were apparently larger and closer in size to the largest precloacal vertebrae from Kohfidisch.

The above listed data on sizes of vertebrae apparently show that the vertebrae from the late Miocene of Kohfidisch (MN 11) are somewhat larger and wider than the vertebrae from the early/middle Miocene of Petersbuch 2 (MN 4) and VieuxCollonges (MN 4/5). The late Miocene $N$. romani from Ravin de la Pluie (MN 10) also retained relatively large-sized vertebrae (about $10 \mathrm{~mm}$ ). The Naja sp. from Maramena (MN 13), which possibly also belongs to $N$. romani, has a centrum length of $c .11 \mathrm{~mm}$ (estimated based on Szyndlar 1995). The Pliocene Naja seemingly varies in size: the Tourkobounia 1 (MN 16) specimen has a centrum length of about $8 \mathrm{~mm}$ and the specimen from Çalta (MN 15) has a centrum length of about $11 \mathrm{~mm}$. We can therefore assume that $N$. romani grew larger through the Miocene and reached its largest size in the latest Miocene with the cobra from Solnechnodolsk being one of the largest specimens of this species.

The Naja from Solnechnodolsk fits well the scenario of extirpation from Europe of the elapid snakes at the end of the Miocene as a result of the climatic deterioration (Szyndlar \& Rage 1990; Ivanov 2001). Although the cobras (as Naja sp.) are still present in the Pliocene of west (Spain and France) and east (Greece and Turkey) of the Mediterranean region, the large-sized Naja romani disappeared entirely before the end of the Miocene in Europe. Remains of this fossil cobra are well known from several European countries from the period between the early ( $\mathrm{MN} 4)$ through the late (MN 11)

FIG. 2. - The precloacal vertebra of Naja romani (Hoffstetter, 1939) from Solnechnodolsk locality in dorsal (A), ventral (B), left lateral (C), right lateral (D), anterior (E) and posterior (F) views. Scale bar: $5 \mathrm{~mm}$. 


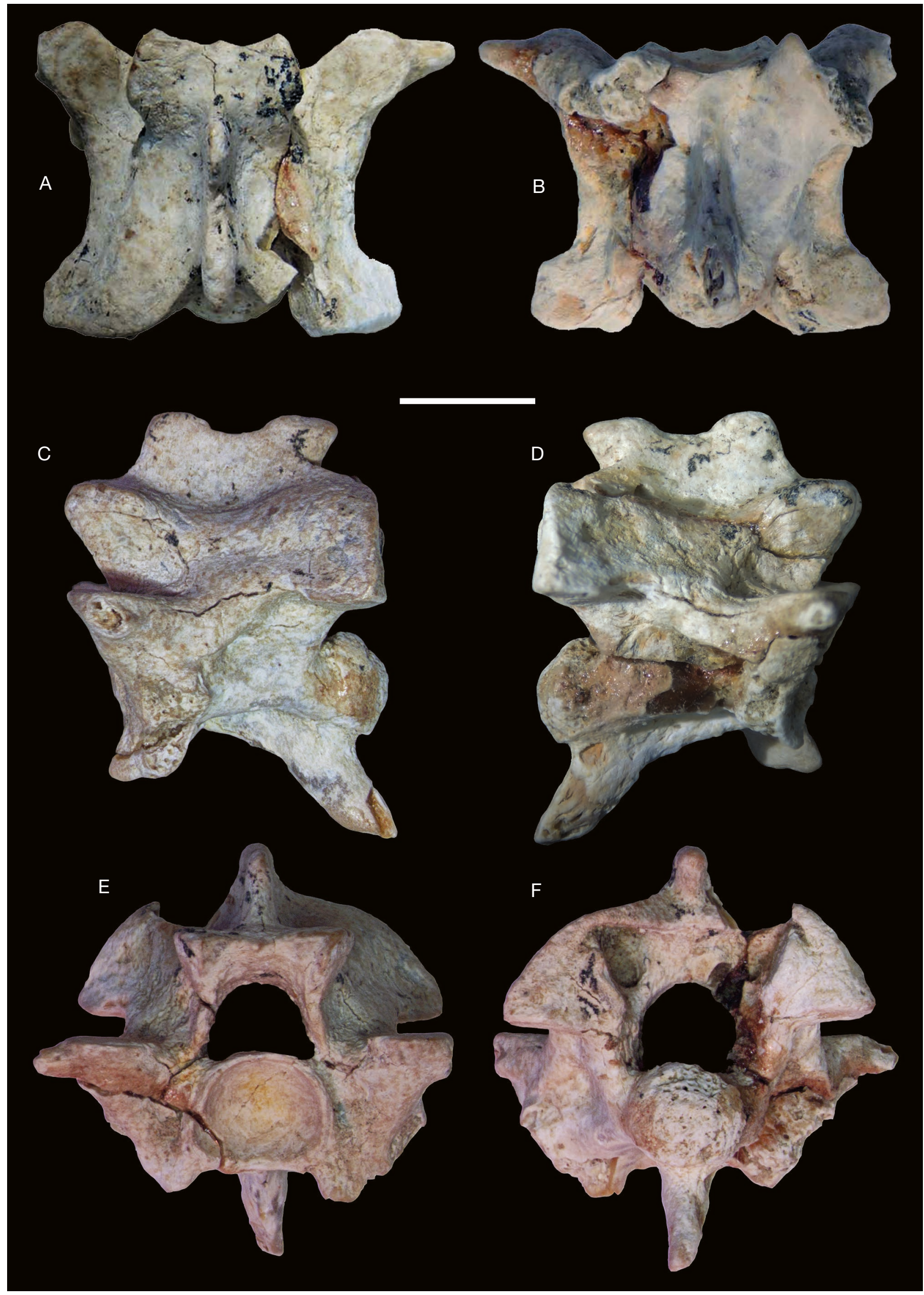


Miocene. Previously, the geologically youngest record of $N a j a$ romani was from the late Miocene (MN 11) of Kohfidisch (Bachmayer \& Szyndlar 1985). The Naja from Solnechnodolsk comes from the terminal Miocene (MN 13) and represents the last known record of the species. Being represented by the single vertebra among numerous fossils in Solnechnodolsk (more than 500 amphibian and reptile remains, personal data), Naja appears to be already sparse in the herpetofaunal assemblages during the end of the Miocene. Nevertheless, this record is the first evidence of the survival of the species until the end of the Miocene in Europe, a time of the Messinian salinity crisis in the Mediterranean region, and a vast marine transgression of the lower Pontian in the Eastern Paratethys area. The late Miocene is marked by climatic changes which affected the snake faunas (Rage 2013). Although climatic conditions remained warm during the Turolian (MN 11-MN 13 mammalian biozones), the snake faunas became less rich and regionalization occurred. In Central Europe, the warm period ended during the middle Miocene and the drop in temperature marked the beginning of climatic zonation. Local extinctions occurred in northern areas whereas some thermophilic species survived in the southern regions of Europe (Rage 2013). Naja disappeared from Central and Eastern Europe, but it appears to have survived into the latest Miocene and Pliocene in the Western (Spain and France) and Eastern (Greece, Turkey, and Northern Caucasus) Mediterranean area. The only reported Pleistocene cobra described as Naja sp. from Chios (Schneider 1975) apparently belongs to a natricine snake (Szyndlar 1991). The latest Miocene and the Pliocene cobras of Spain have undoubtedly an African origin and reached the Iberian Peninsula at the time of the Messinian crisis (Szyndlar 1985). The same is probably true for the Pliocene Naja from the southern France. The record of cobra from Solnechnodolsk points to the existence of the Caucasian refugium where this snake apparently survived into the latest Miocene. Apart from cobra, Solnechnodolsk retained other reptile taxa such as amphisbaenians, Varanus sp., Anguis cf. rarus, Ophisaurus cf. spinari (Čerňanský et al. 2018), which also disappeared from Central Europe before the end of the Miocene.

The Naja record is a new element for Solnechnodolsk fauna, which includes about 30 amphibian and reptile taxa (Čerňanský et al. 2018; Čerňanský \& Syromyatnikova 2019a, b; Syromyatnikova, pers. observ.). It also represents a first record of cobra for Russia and for the Northern Black Sea area that significantly contributes to the knowledge on the ancient biodiversity of the region and suggests a wider geographic range of the genus. Naja romani is evidently a thermophilous snake. Although Asian affinities are suggested for Naja romani, nothing is known about ecological preferences of this extinct cobra. Most living members of the genus Naja inhabiting the Asiatic continent today are highly thermophilous (Szyndlar 2009). However, N. oxiana, the Caspian cobra, is adapted to more severe climatic conditions. Together with the occurrence of Varanus sp., suggesting a mean annual temperature not less than $15^{\circ} \mathrm{C}$ (Böhme 2003; Čerňanský et al. 2018), the record of $\mathrm{Naja}$ indicates subtropical climatic conditions for the squamate fauna of Solnechnodolsk.

\section{Acknowledgements}

We thank the fellow members of the expeditions to the Solnechnodolsk locality from the Institute of Arid zones (Southern Scientific Centre, Rostov-on-Don) and Geological Institute of the Russian Academy of Sciences (Moscow). We thank the late J.-C. Rage (Muséum national d'Histoire naturelle, Paris, France) for a great help and information about Naja fossils, Christopher Bell (University of Texas at Austin) and anonymous reviewer for their comments and suggestions, which greatly improved the manuscript. We thank Emmanuel Côtez (Muséum national d'Histoire naturelle, Paris, France) for editorial assistance. The study was supported by the Russian Scientific Fund no. 18-74-10081.

\section{REFERENCES}

BaChMaYer F. \& SZyndlar Z. 1985. - Ophidians (Reptilia: Serpentes) from the Kohfidisch fissures of Burgenland, Austria. Annalen des Naturhistorischen Museums Wien A 87: 79-100. https://www.jstor.org/stable/41701718

BACHMAYER F. \& SZYNDLAR Z. 1987. - A second contribution to the ophidian fauna (Reptilia: Serpentes) of Kohfidisch, Austria. Annalen des Naturhistorischen Museums Wien A 88: 25-39. https://www.jstor.org/stable/41701854

BAILON S. 1989. - Les amphibiens et les reptiles du Pliocène supérieur de Balaruc II (Hérault, France). Palaeovertebrata 19 (1): 7-28.

BAILON S. 1991. - Amphibiens et reptiles du Pliocène et du Quaternaire de France et d'Espagne: mise en place et évolution des faunes. $\mathrm{PhD}$ thesis, Université de Paris, Paris, France, 499 p.

BAILON S. \& BLAIN H. A. 2007 - Faunes de reptiles et changements climatiques en Europe occidentale autour de la limite Plio-Pléistocène. Quaternaire 18 (1): 55-63. https://doi.org/10.4000/ quaternaire.960

BöHME M. 2003. - The Miocene climatic optimum: evidence from ectothermic vertebrates of Central Europe. Palaeogeography, Palaeoclimatology, Palaeoecology 195: 389-401. https://doi. org/10.1016/S0031-0182(03)00367-5

ČERÑANSKÝ A. \& SYROMYATNIKOVA E. V. 2019a. - The first Miocene fossils of Lacerta cf. trilineata (Squamata, Lacertidae) with a comparative study of the main cranial osteological differences in green lizards and their relatives. PLoS ONE 14 (8): e0216191. https://doi.org/10.1371/journal.pone.0216191

ČERÑANSKÝ A. \& SYROMYATNIKOVA E. V. 2019b. - The first preQuaternary fossil record of the clade Mabuyidae with a comment on the enclosure of the Meckelian canal in skinks. Papers in Palaeontology 7 (1): 195-205. https://doi.org/10.1002/spp2.1279

ČERŇANSKÝ A., SYROMYATNIKOVA E. V. \& JABLONSKI D. 2018. The first record of amphisbaenian and anguimorph lizards (Reptilia, Squamata) from the upper Miocene Solnechnodolsk locality in Russia. Historical Biology 32 (7): 869-879. https:// doi.org/10.1080/08912963.2018.1539973

Georgalis G. L., Rage J.-C., Bonis L. De \& Koufos G. 2018. Lizards and snakes from the late Miocene hominoid locality of Ravin de la Pluie (Axios Valley, Greece). Swiss Journal of Geosciences 111 (1-2): 169-181. https://doi.org/10.1007/s00015-017-0291-2 Georgalis G. L., Villa A., Ivanov M., Vasilyan D. \& Delfino M. 2019. - Fossil amphibians and reptiles from the Neogene locality of Maramena (Greece), the most diverse European herpetofauna at the Miocene/Pliocene transition boundary. Palaeontologia Electronica 22.3.68: 1-99. https://doi.org/10.26879/908

HoffstetTer R. 1939. - Contribution à l'étude des Elapidae actuels et fossiles et de l'ostéologie des Ophidiens. Archives du Muséum d'Histoire naturelle de Lyon 15: 1-78. 
IVANOv M. 2000. - Snakes of the lower/middle Miocene transition at Vieux Collonges (Rhône, France), with comments on the colonisation of western Europe by colubroids. Geodiversitas 22 (4): 559-588.

IVANOV M. 2001. - Changes in the composition of the European snake fauna during the early Miocene and at the early/middle Miocene transition. Paläontologische Zeitschrift 74: 563-573. https://doi.org/10.1007/BF02988162

JAEN M. J. \& SANCHIZ B. 1985. - Fossil snakes from the Pliocene of Layna, central Spain, in European Herpetological Meeting, 19-23 August 1985, Prague, Abstracts: 72.

Polly P. D., Head J. J. \& Cohn M. J. 2001. — Testing modularity and dissociation: the evolution of regional proportions in snakes, in ZeLDiTCH M. L. (ed.), Beyond Heterochrony: The Evolution of Development. John Wiley \& Sons, New York: 307-335.

Quadros A. B., Mahlow K., Jalil N. E. \& Zaher H. 2019. - Phylogenetic Affinities of the Fossil Elapids Naja romani and Naja antiqua (Serpentes: Elapidae). Journal of Morphology 280: 207. https://doi.org/10.1002/jmor.21003

RAGE J.-C. 2013. - Mesozoic and Cenozoic squamates of Europe. Palaeobiodiversity and Palaeonvironments 93: 517-534. https:// doi.org/10.1007/s12549-013-0124-x

RAGE J.-C. \& SEN S. 1976. - Les amphibiens et les reptiles du Pliocène supérieur de Çalta (Turquie). Géologie méditerranéenne 3: 127-134. https://doi.org/10.3406/geolm.1976.969

SCHNEIDER B. 1975. - Ein mittelpleistozane Herpetofauna von der Insel Chios, Agais. Senckenbergiana Biologica 56: 191-198.

Syromyatnikova E. V. 2019. - Redescription of Pelobates praefuscus Khosatzky, 1985 and new records of Pelobates from the Late Miocene-Pleistocene of Eastern Europe. Historical Biology 31 (7): 888-897. https://doi.org/10.1080/08912963 .2017 .1402015 .

SyromyatnikOVA E. V., TeSAKOV A. S. \& Titov V. V. 2015. Preliminary report on herpetofauna from the Solnechnodolsk locality (Late Miocene), Russia, 75th Annual Meeting, Abstracts, Supplement to the online Journal of Vertebrate Paleontology: 221.

SZYNDLAR Z. 1985. - Ophidian fauna (Reptilia, Serpentes) from the uppermost Miocene of Algora (Spain). Estudios Geológicos 41: 447-465. https://doi.org/10.3989/egeol.85415-6725

SZYNDLAR Z. 1991. - A review of Neogene and Quaternary snakes of Central and Eastern Europe. Part II: Natricinae, Elapidae, Viperidae. Estudios Geológicos 47: 237-266.
SZYNDLAR Z. 1995. - The Vertebrate Locality Maramena (Macedonia, Greece) at the Turolian-Ruscinian Boundary (Neogene). Münchner Geowissenschaftliche Abhandlungen A 28: 39-42.

SZYNDLAR Z. 2005. - Snake fauna from the Late Miocene of Rudabánya. Palaentographia Italica 90: 31-52.

SZYNDLAR Z. 2009. - Snake fauna (Reptilia: Serpentes) from the Early/ Middle Miocene of Sandelzhausen and Rothenstein 13 (Germany). Paläontologische Zeitschrift 83: 55-66. https://doi. org/10.1007/s12542-009-0009-5

SZyNDlar Z. \& Rage J.-C. 1990. - West Palearctic cobras of the genus Naja (Serpentes: Elapidae): interrelationships among extinct and extant species. Amphibia-Reptilia 11: 385-400. https://doi. org/10.1163/156853890X00078

SZYNDLAR Z. \& SCHLEICH H. H. 1993. - Description of Miocene Snakes from Petersbuch 2 with comments on the Lower and Middle Miocene Ophidian faunas of southern Germany. Stuttgarter Beiträge zur Naturkunde (Serie B) 192: 1-47.

SZYNDLAR Z. \& ZEROVA G. 1990. - Neogene cobras of the genus Naja (Serpentes: Elapidae) of East Europe. Annalen des Naturhistorischen Museums in Wien 91A: 53-61. https://www.jstor.org/ stable/41701893

Tempfer P. M. 2003. - The Miocene herpetofaunas of Grund (Caudata; Chelonii, Sauria, Serpentes) and Mühlbach am Manharstsberg (Chelonii, Sauria, Amphisbaenia, Serpentes), Lower Austria. Annalen des Naturhistorischen Museums in Wien 104: 195-235.

Tempfer P. M. 2005. - The herpetofauna (Amphibia: Caudata, Anura; Reptilia: Scleroglossa) of the Upper Miocene locality Kohfidisch, Burgenland, Austria. Beiträge zur Paläontologie 29: $145-253$.

Tesakov A. S., Titov V. V., Shvyreva A. K., Syromyatnikova E. V. \& Frolov P. D. 2010. — Solnechnodolsk - new locality of Late Miocene vertebrates at Northern Caucasus, in The evolution of organic life and biotic crisises, 56, Conference of Russian Paleontological Society at Saint Petersburg, Russia: 137

Tesakov A. S., Titov V. V. \& SotnikOVA M. V. 2013. — Late Miocene (Turolian) mammal faunas of the southern European Russia. Collection of Scientific Contributions of the Institute of Geological Sciences of the National Academy of Sciences of Ukraine 6 (1): 164-176.

Titov V. V. \& TesakOV A. S. 2013. - Late Miocene (Turolian) vertebrate faunas of the southern European Russia, in WANG X., FlynN L. J. \& ForTelius M. (eds), Fossil Mammals of Asia: Neogene Biostratigraphy and Chronology. Columbia University Press, New York: 536-543.

Submitted on 26 September 2019; accepted on 23 March 2020; published on 23 September 2021. 